\title{
Multimedia Interaktif tipe Adobe Flash CS6 Berbasis kurikulum 2013 dalam Meningkatkan Literasi Verbal Siswa Sekolah Dasar
}

\author{
Dwi Agus Setiawan', Farida Nur Kumala ${ }^{2}$ \\ alamat Email: Setiawan@unikama.ac.id ${ }^{1}$, faridankumala@ unikama.ac.id ${ }^{2}$ \\ PGSD, FKIP, Universitas Kanjuruhan Malang \\ No Handphone: 085779925655
}

\begin{abstract}
Abstrak: Multimedia Interaktif Adobe flash CS6 merupakan media pembelajaran interaktif yang berbasis computer yang dikemas dalam sebuah CD (Compact Disk) yang didalamnya terdapat aplikasi interaktif dan juga memiliki komponen menu yang dapat di klik untuk dapat menampilkan suatu informasi tertentu didalamnya. Multimedia interaktif ini menggunakan kurikulum 2013 sebagai pedoman dalam mengemas pembelajaran yang interaktif dengan meningkatkan literasi verbal siswa SD. Penelitian dan pengemabangan ini bertujuan untuk (1) Menghasilkan produk berupa multimedia interaktif berbasis pembelajaran 2013 menggunakan software Adobe flas CS6. (2) Mengetahui kelayakan multimedia interaktif berbasis kurikulum 2013. 3) Mengetahui respon siswa terhadap multimedia pembelajaran interaktif tipe Adobe flash CS6 berbasis pembelajaran kurikulum 2013 dalam meningkatkan literasi verbal siswa SD. Metode penelitian ini menggunakan metode Research and Development (R\&D) dengan mengadopsi model ADDIE meliputi: analysis yaitu melakukan analisis kurikulum, analisis kebutuhan, analisis materi; design meliputi pengumpulan isi materi dan soal, desain tampilan, story board, komponen-komponen; development yaitu pembuatan media dan melakukan validasi ahli; implementasi yaitu uji coba produk; Evaluasi yaitu pembahasan produk setelah uji coba. Instrumen penelitian yang digunakan observasi, wawancara, dokumentasi dan kuesioner. Teknik analisis data yang digunakan yaitu analisa deskriptif presentase. Data hasil penelitian dari uji coba lapangan terbatas berjumlah 6 siswa dengan hasil presentase 83,3\% dengan kategori "Valid" untuk digunakan oleh siswa kelas II SD sebagai sumber belajar. Uji coba lapangan lebih luas berjumlah 30 siswa dengan hasil presentase 92,7\% dengan kategori "Sangat Valid" karena dengan menggunakan multimedia in teraktif ini sisiwa menjadi semangat belajar dan menjadi lebih aktif untuk digunakan oleh siswa kelas II SD sebagai sumber belajar, sedangkan hasil uji literasi verbal siswa mendapatkan persentase $86,20 \%$ dengan katagori sangat baik dan menambah pemahaman kepada peserta didik untuk memilki rasa antusias yang tinggi dalam gemar membaca. Saran pengembangan produk multimedia interaktif ini Perlu ada pelatihan bagi guru-guru dalam pembuatan multimedia.
\end{abstract}

Kata kunci: Multimedia Interaktif tipe Adobe Flash CS6, Kurikulum 2013 , Literasi Verbal 
Dwi, Farida. Multimedia Interaktif tipe Adobe...

\title{
Interactive Multimedia Adobe Flash CS6 type Based on the 2013 Curriculum in Improving Verbal Literacy of Primary School Students
}

\begin{abstract}
Interactive Multimedia Adobe Flash CS6 is a computer-based interactive learning media that is packaged in a CD (Compact Disk) in which there is an interactive application and also has a menu component that can be clicked on to display certain information in it. This interactive multimedia uses the 2013 curriculum as a guide in packaging interactive learning by increasing the verbal literacy of elementary school students. This research and development aims to (1) Produce a product in the form of interactive multimedia based on learning 2013 using Adobe flas CS6 software. (2) Knowing the feasibility of interactive curriculum-based multimedia 2013. 3) Knowing student responses to interactive learning multimedia type Adobe Flash CS6-based learning curriculum 2013 in improving verbal literacy of elementary school students. This research method uses the Research and Development (R\&D) method by adopting the ADDIE model which includes: analysis which is conducting curriculum analysis, needs analysis, material analysis; design includes gathering material and questions, display design, story board, components; development, namely media creation and expert validation; implementation of product trials; Evaluation is a discussion of the product after the trial. The research instrument used was observation, interviews, documentation and questionnaires. The data analysis technique used is descriptive analysis of percentages. Research data from limited field trials amounted to 6 students with a percentage of $83.3 \%$ with the category "Valid" to be used by grade II elementary school students as a learning resource. Broader field trials totaling 30 students with a percentage of $92.7 \%$ with the category "Very Valid" because by using this multimedia in most active students become a spirit of learning and become more active for use by students in grade II elementary school as learning resources, while the test results verbal literacy students get a percentage of $86.20 \%$ with a very good category and add understanding to students to have a high enthusiasm in reading. Suggestions for developing this interactive multimedia product There needs to be training for teachers in making multimedia.
\end{abstract}

Keywords: Interactive Multimedia Adobe Flash CS6 type, 2013 Curriculum, Verbal Literacy

\section{PENDAHULUAN}

Dunia digital saat ini memiliki peranan yang sangat penting bagi perkembangan teknologi dan informasi, komunikasi dan sangat dibutuhkan dalam dunia pendidikan guna mengikuti perkembangan zaman yang terus berkembang dengan pesat. Senada dengan 
Dwi, Farida. Multimedia Interaktif tipe Adobe...

(Hartanto, 2013) bahwa "Multimedia adalah kombinasi teks, grafik, suara, animasi dan video. Bila pengguna mendapatkan keleluasaan dalam mengontrol maka disebut multimedia interaktif'. (Kusprimanto,2014) Salah satu multimedia interaktif pembelajaran yang peneliti kembangkan adalah multimedia berbasis komputer yang dalam hal ini Adobe Flash Profesional CS6. Menurut (Susiana, Harningsih, \& Napitupulu, 2014) Adobe Flash Profesional CS6 banyak dimanfaatkan untuk membuat animasi, game, presentasi maupun multimedia pembelajaran. Di dalam flash kita dapat memasukan rumus dalam bentuk action script, video, suara, animasi 2D dan 3D. Alasan peneliti memilih mengembangkan multimedia interaktif adalah fasilitas TIK (Teknologi informasi dan komunikasi) di SDN Karangsuko 02 cukup memadai tetapi guru kurang memanfaatkan fasilitas tersebut, metode pembelajaran yang digunakan guru diluar kelas pada subtema 2 bermain dirumah teman kurang sesuai dengan kondisi siswa kelas II sehingga anak gaduh saat diluar kelas, siswa juga merasa bosan dan mengantuk karena kurangnya keterampilan guru dalam memanfaatkan media sehingga pembelajaran kurang menarik dan belum adanya produk berupa pengembangan multimedia interaktif pada subtema bermain dirumah teman, pembelajaran 4, (Kurniawati,2014) multimedia pembelajaran yang dibuat menarik dan interaktif sehingga mengaktifkan siswa dan membuat siswa termotivasi untuk belajar, umpan balik dan juga mendorong siswa untuk menerapkan pembelajaran dalam kehidupan sehari-hari serta menghemat ruang dan waktu. (Putry \& Agung Listiadi”, 2012) Multimedia biasanya dikemas dalam CD (compact disk). CD (compact disk) merupakan salah satu hasil implementasi dari multimedia, dimana hampir semua konten multimedia terdapat dalam satu keping $\mathrm{CD}$, yaitu berupa gambar, video, animasi, teks dan audio.

Dari uraian di atas, maka dapat memberikan pemahaman bahwa tanpa bantuan media, maka materi pembelajaran sukar untuk dicerna dan dipahami oleh siswa, terutama materi pembelajaran yang rumit dan komplek. Pengertian media pendidikan seperti diatas di dasarkan pada asumsi bahwa proses pendidikan atau pembelajaran identik dengan sebuah proses komunikasi. Dalam proses komunikasi terdapat komponen-komponen yang terlibat di dalamnya yaitu sumber pesan, pesan, penerima pesan, media, dan umpan balik.

(Setiadi, 2016) Mengemukakan dalam kurikulum 2013 pendekatan pembelajaran yang digunakan adalah pendekatan saintifik (scientific). Penjelasan pendekatan saintifik sendiri menurut Kemendikbud dalam Materi Pelatihan Guru Implementasi Kurikulum 2013 "Pendekatan scientific dilakukan melalui proses kegiatan mengamati, menanya, 
Dwi, Farida. Multimedia Interaktif tipe Adobe...

mengumpulkan, informasi/eksperimen, mengasosiasi/mengolah, informasi, dan mengkomunikasikan". Pada penelitian ini peneliti melakukan penelitian di kelas II semester I pada Tema 2 bermain dilingkunganku, Subtema 2 bermain rumah teman, Pembelajaran 4, alasan mengambil tema tersebut yaitu pada saat peneliti melakukan observasi di kelas II semester I ada permasalahan di kelas dan di luar kelas membuat konsentrasi belajar terpecah bahkan membuat kondisi kelas menjadi tidak kondusif, contohnya seperti peserta didik tidak fokus pada pembelajaran, mengantuk, lebih memilih berbicara sendiri dengan temannya, berkelahi saat diluar kelas dan ada yang merasa jenuh dengan pembelajaran, kemungkinan faktor guru yang cara penyampaian materi membosankan, atau pendekatan dan media yang digunakan guru kurang membuat peserta didik antusias, serta bermacam-macam masalah yang timbul. Kurikulum merupakan suatu rencana yang memberi pedoman atau pegangan dalam proses kegiatan belajarmengajar (Trianto, 2015:102). Kurikulum 2013 tidak hanya menekankan kepada pengusaan kompetensi siswa, melainkan juga pembentukkan karakter. Sesuai dengan kompetensi inti (KI) yang telah ditentukan oleh Kemendikbud, KI 1 dan KI 2 berkaitan dengan tujuan pembentukkan karakter siswa sedangkan KI 3 dan KI 4 berkaitan dengan penguasaan kompetensi siswa.

Pendidikan membutuhkan alat yaitu kurikulum untuk mengembangkan pribadinya ke arah ke arah tujuan pendidikan, kurikulum membutuhkan guru kehadiran kurikulum dapat mempermudah guru melaksanakan pelajaran dikelas. Kurikulum dapat membantu guru untuk mengelola kelas dengan baik, merencanakan pembelajaran dan mencapai tujuan pendidikan. Dalam proses pembelajaran terdapat beberapa komponen dua diantaranya adalah guru dan siswa. (Mulyasa, 2011:187). Dalam membangun inovasi pengajaran yang manarik, perlu adanya Guru profesional bukan hanya perlu persiapan materi pelajaran saja, tetapi juga dituntut kreatif menggunakan dan mengembangkan media pembelajaran. Berangkat dari permasalahan tersebut peneliti ingin mengetahui apa saja yang menjadi problematika guru dalam proses pelaksanaan pembelajaran dalam kurikulum 2013 tentunya pada pemanfaatan media untuk membiasakan dalam membaca menulis dan berbicara secara verbal pada siswa.

Berangkat dari permasalahan tersebut peneliti ingin mengetahui apa saja yang menjadi problematika guru dalam proses pelaksanaan pembelajaran dalam kurikulum 2013 tentunya pada pemanfaatan media untuk membiasakan dalam membaca menulis dan 
Dwi, Farida. Multimedia Interaktif tipe Adobe...

berbicara secara verbal pada siswa. Meskipun demikian, tantangan yang saat ini dihadapi adalah rendahnya minat baca. Selain ketersediaan buku di seluruh Indonesia belum memadai, pemerintah juga menghadapi rendahnya motivasi membaca di kalangan peserta didik. Hal ini memprihatinkan karena di era teknologi informasi, peserta didik dituntut untuk memiliki kemampuan membaca dalam pengertian memahami teks secara analitis, kritis dan reflektif. Sesungguhnya permasalahan umum dalam dunia literasi di Indonesia adalah rendahnya ikatan emosional terhadap sumber informasi salah satunya buku bacaan dan kegiatan pemanfaatan sumber informasi tersebut atau kegiatan membaca dan berbicara dalam budaya literasi di sekolah. (Nurgiyantoro \& Suyata, 2011) Literasi berasal dari kata literacy yang artinya melek huruf, kemampuan baca tulis, kemelekwancanaan atau kecakapan dalam membaca dan menulis Kurniati (2016:7) mengatakan bahwa "verbal adalah bagian dari komunikasi. Komunikasi verbal adalah berbicara yang menggunakan bahasa lisan maupun tulisan. Ada 2 jenis komunikasi verbal yang pertama yaitu, berbicara dan menulis, berbicara adalah komunikasi verbal vocal, sedangkan menulis adalah komunikasi verbal non vocal. Kedua yaitu, mendengar dan berbicara

Literasi Verbal seringkali dikaitkan dengan kemampuan membaca atau pengetahuan yang bersifat tulisan, seperti yang diungkapkan oleh (Lau, Setiawan, \& Werdiningtiyas, 2019) berdasarkan asal katanya, litterae berarti kumpulan huruf, maka literate dapat diartikan sebagai orang yang memiliki kemampuan atau kompetensi akan suatu pengetahuan, atau ia dapat membaca atau menulis, dan punya kemampuan untuk memanfaatkan pengetahuan tersebut. Terkait dengan buku sebagai salah satu sumber informasi, rendahnya minat dan gairah membaca sebagian berakar dari masih kuatnya tradisi lisan dalam kehidupan sosial dan pola berpikir masyarakat Indonesia di tingkat dasar.

Dari uraian di atas, maka dapat memberikan pemahaman bahwa Kebutuhan media pembelajaran yang aplikatif diperlukan dalam usaha untuk memudahkan proses belajar mengajar, seperti halnya multimedia pembelajaran interaktif.(Akbar, 2016) Media pembelajaran ini, dimaksudkan sebagai alat bantu pembelajaran, dalam bentuk software Adobe Flash Profesional CS6. Media pembelajaran ini dimaksudkan untuk mempermudah siswa dalam mempelajari Tematik, tema 2 bermain dilingkunganku. Peneliti melakukan penelitian di kelas II semester I pada Tema 2 bermain dilingkunganku, Subtema 2 bermain rumah teman, Pembelajaran 4. Alasan mengambil tema tersebut yaitu karena pada materi 
Dwi, Farida. Multimedia Interaktif tipe Adobe...

Tema 2 bermain dilingkunganku, Subtema 2 bermain rumah teman, Pembelajaran 4, membutuhkan media yang beragam yaitu media matematika perkalian, animasi menari, gambar wujud benda, untuk menyiasati media yang banyak tersebut peneliti memanfaat teknologi yang semakin canggih menggabungkan video, gambar, audio dan animasi untuk membuat siswa semangat dan antusias dalam belajar serta membuat siswa tidak jenuh dan mempermudah memahami materi, dikelas II belum pernah tahu multimedia interaktif dan guru belum pernah menggunakan multimedia pembelajaran interaktif dalam pembelajaran dan juga supaya pembelajaran efektif serta menyenangkan sehingga pusat perhatian siswa berada satu titik guru juga dipermudah karena pengelolaan kelas lebih mudah dan terarah.

Fokus penelitian pada kelas IIb yang terdiri dari 30 siswa. fasilitas yag ada di kelas IIb lengkap mulai dari meja, kursi, papan tulis, LCD dan sebagainya. Ketika proses belajar mengajar guru Guru kelas menyusun dan melaksanakan rancangan pembelajaran yang mendidik, ini terbukti rancangan pembelajaran yang dibuat guru kelas sudah menggunakan PPK yaitu; penguatan pendidikan karakter yang ditulis jelas di rancangan pembelajaran. Rancangan pembelajaran yang dibuat guru tidak harus sama persis dengan buku guru maupun buku siswa, tetapi guru memodifikasi sesuai kebutuhan peserta didiknya dan disesuaikan dengan kemampuan peserta didiknya. Tetapi dalam memanfaatkan teknologi informasi komunikasi (TIK) untuk kepentingan pembelajaran, guru kelas kurang memanfaatkan fasilitas yang ada seperti LCD dan guru belum pernah menampilkan multimedia interaktif kepada siswa Pengamatan pada saat penelitian di kelas II di SDN Karangsuko 02 guru melakukan penilaian pada Kompetensi Inti 1 dan 2 yaitu religius dan sikap, penilaian Kompetensi Inti 3 dan 4 yaitu kognitif dan psikomotor. Karena keberhasilan tujuan pembelajaran pada kurikulum 2013 yaitu mencakup keempat penilaian pada KI 1, KI 2, KI 3, KI 4. Dalam proses belajar mengajar ada banyak faktor yang mempengaruhi tercapainya tujuan pembelajaran diantaranya pendidik, peserta didik, lingkungan, metode/teknik serta media pembelajaran, untuk menjankan ketercapaian tujuan pembelajaran tersebut perlunya kompetensi guru. Sesuai penjabaran latar belakang diatas peneliti tanpa bermaksud mengabaikan salah satu kompetensi guru yang ada, dalam penelitian ini hanya akan dibahas tentang pengembangan multimedia Interaktif berbasisi kurikulum 2013 untuk meningkatkan literasi verbal anak. Penelitian ini difokuskan pada kelas II, Semester I, Tema 2: Bermain dilingkunganku, Subtema 2: bermain dirumah teman, Pembelajaran ke 4. Oleh karena itu penelitian ini di fokuskan pada Multimedia 
Dwi, Farida. Multimedia Interaktif tipe Adobe...

Interaktif pada kurikulum 2013 dengan literasi verbal anak di tingkat dasar. Penelitian ini adalah penelitian pengembangan. Jenis penelitian yang digunakan adalah jenis penelitian dan pengembangan atau Research and Development (R\&D) yaitu suatu proses atau langkah-langkah untuk mengembangkan suatu produk baru menyempurnakan produk yang ada, yang dapat dipertanggung jawabkan, Sukmadinata 2013: 167. Salah satu model yang dipilih adalah model ADDIE yaitu model Analysis (Analisis), Design (Merancang), Development (Mengembangkan), Implementation (mengimplementasian), dan Evaluastion (Mengevaluasi) (Pribadi, 2014:23). Alasan peneliti menggunakan model ini untuk menghasilkan produk tertentu, dan menguji keefektifan produk tersebut. (Sugiyono, 2009:407). Tujuan penelitian dalam artikel ini adalah : Menghasilkan prodak berupa multimedia interaktif adope flash, tingkat kelayakan dari multimedia Interaktif, Melihat respon siswa terhadap penggunaan multimedia Interaktif dengan kurikulum 2013 dan juga tingkat literasi verbal siswa dalam membaca.

\section{METODE}

Penelitian ini merupakan jenis penelitian dan pengembangan atau dalam bahasa inggrisnya Research and Development (R\&D) yang digunakan untuk menghasilkan produk tertentu, dan menguji keefektifan produk tertentu (Sugiyono 2015:407). Menurut pribadi (2004:22) Ada beberapa model yang dapat digunakan untuk mendesain dan mengembangkan program pembelajaran. Salah satu model yang dapat diimplementasikan untuk mendesain dan mengembangkan multimedia interaktif adalah model ADDIE. Alasan peneliti mengambil penelitian pengemabangan model ini merupakan model yang dikhususkan untuk mengambangkan bahan ajar berbasisi multimedia. Model pengembangan dikatakan model procedural karena urutan langkah dalam proses tersususn secara sistematis runtut dalam setiap langkah dan tahapan yang tersususn secara jelas. Prosedur penelitian dan pengemabngan dengan menggunakan model ADDIE terdiri dari 5 tahapan yaitu: (1) Analisis (2) Merancang (3) mengemabangkan (4)Mengimplementasikan (5) Evaluasi. 
Dwi, Farida. Multimedia Interaktif tipe Adobe...

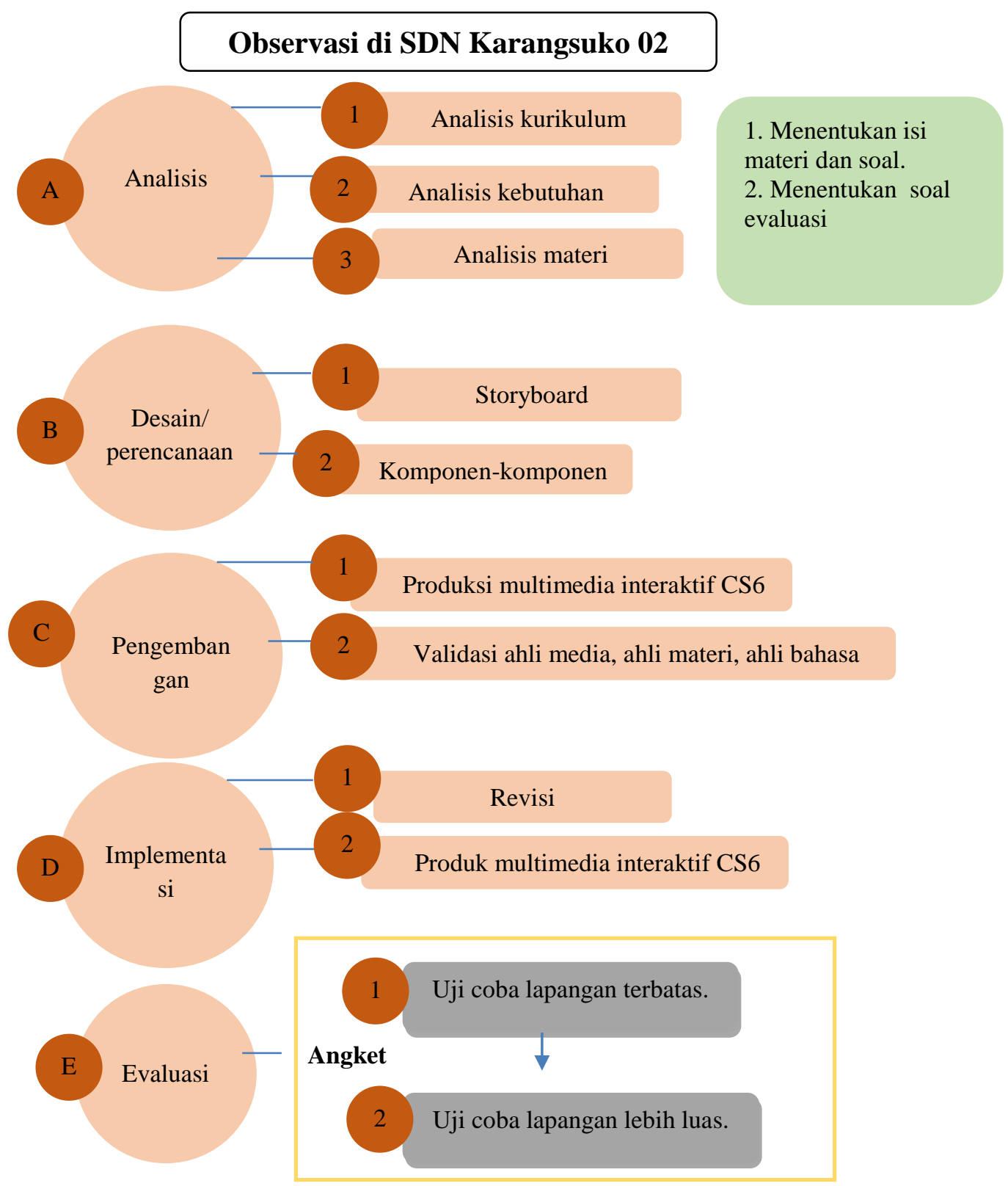

Gambar 1.1 Tahap penelitian (Sumber: Pribadi, 2014)

Subjek penelitian ini adalah Siswa yang terdiri dari 45 siiswa dan guru, ahli media dan ahli materi. Penelitian ini juga diuji cobakan kepada siswa dalam kelompok kecil dan kelompok besar dilapangan, guru. Pada pelaksaan uji coba ini bertujuan untuk mengetahui tingkat kepraktisan, kemenarikan dan tingkat respon sisiwa terhadap keefektifan media. Jenis data dalam penelitian pengembangan ini yaitu data kualtatif yang didapat pada pengisisan angket dan data kuantitatif yasng di dapat dari hasil angket dan tingkat respon siswa. Instrumen pengumpulan data yang digunakan yaitu 
Dwi, Farida. Multimedia Interaktif tipe Adobe...

pedoman observasi,wawancara,angket dan tes soal. Angket digunakan untuk menilai validitas media dari ahli media,ahli bahasa dan materi untuk ahli materi ,Angket juga digunakan untuk menilai tingkat kepraktisan dan kemenarikan sedangkan untuk menilai keefektifan dari segi sisiwa digunkan post test.

Dalam penelitian ini teknik analisis data yang digunakan dalam penilaian multimedia interaktif dilakukan secara kuantitatif dan kualitatif. Analisis data dalam penelitian ini dimaksudkan untuk menjawab berbagai permasalahan yang terkait dengan pengembangan guna merumuskan kesimpulan dari hasil pengembangan. Teknik analisa yang digunakan dalam penelitian ini adalah teknik analisa deskriptif presentase. Data yang diperoleh kemudian diinterpresentasikan dengan kalimat bersifat kualitatif.

\section{HASIL}

Hasil dari Penilaian kualitas media pembelajaran tema 2, subtema 2 bermain di rumah teman, pembelajaran 4 berbasis literasi verbal siswa pada sisiwa SDN Karangsuko 02 Dari ke-23 item pernyataan angket tersebut terbagi atas 6 kriteria diantaranya kriteria kebenaran, kriteria keluasan dan kedalaman, kriteria kebahasaan yang digunakan dan kriteria tampilan dengan skor maskimum 92. Tingkat jawaban yaitu: $S B=4, B=3, K B=2$, $\mathrm{TB}=1$. Dari item pernyataan terdapat terdapat 23 jawaban $\mathrm{SB}=4$ kategori Sangat Baik. Berdasarkan data yang diperoleh akan dihitung besar presentasinya dengan cara membandingkan antara jumlah nilai yang dicapai dengan jumlah nilai maksimum kemudian dikalikan $100 \%$ perhitungannya sebagai berikut:

$$
\text { Persentase kelayakan }=\frac{\text { skor yang diperoleh }}{\text { skor } \text { masksimal ideal }} \times 100 \%=\frac{92}{92} \times 100 \%=100 \%
$$

Hasil sajian data tingkat kelayakan dari ahli media, ahli materi, dan ahli bahasa akan direkapitulasi berdasarkan persentase, saran dan komentar yang diberikan sebagai perbaikan produk buku teks berbasis literasi membaca. Hasil data kelayakan produk tersaji pada tabel 1 sebagai berikut. Dari perhitungan di atas didapatkan presentase sebesar $100 \%$. Presentase tersebut termasuk dalam katagori sangat valid dengan kritik dan saran seperti tabel 4.4 sebagai berikut: 
Dwi, Farida. Multimedia Interaktif tipe Adobe...

Tabel 1.1 Rekapitulasi persentase Hasil Validasi Ahli

\begin{tabular}{cccc}
\hline No & Validator & $\begin{array}{c}\text { Persentase } \\
\text { Perolehan }\end{array}$ & Kriteria Penilaian \\
\hline 1. & Ahli media & $92,8 \%$ & Layak, sedikit perbaikan \\
\hline 2. & Ahli materi & $92,19 \%$ & Layak, sedikit perbaikan \\
\hline 3. & Ahli bahasa & $84,38 \%$ & Layak, sedikit perbaikan \\
\hline
\end{tabular}

Hasil validasi materi pembelajaran tematik kurikulum 2013 dari ke-16 item pernyataan angket tersebut terbagi atas 4 kriteria diantaranya kriteria kebenaran, kriteria keluasan dan kedalaman, kriteria kebahasaan yang digunakan dan kriteria evaluasi dengan skor maskimum 64. Tingkat jawaban yaitu: $\mathrm{SB}=4, \mathrm{~B}=3, \mathrm{~KB}=2, \mathrm{~TB}=1$. Dari item pernyataan terdapat 5 item jawaban $\mathrm{B}=3$ katagori Baik, terdapat 11 jawaban $\mathrm{SB}=4$ kategori Sangat Baik dengan skor $92,19 \%$

Sedangkan hasil validasi ahli bahasa dalam media ini dilihat dari Bahasa Pada teks akan lebih menarik bila menggunakan karakter lain. Menyusun bahasa untuk anak usia SD sebaiknya terperinci tidak dalam bentuk paragraf Dari ke-8 item pernyataan angket tersebut terbagi atas 5 kriteria diantaranya kriteria lugas, komunikatif, dialogis dan interaktif, kesesuaian dengan perkembangan siswa, kesesuaian dengan kaidah bahasa indonesia dengan skor maskimum 32. Tingkat jawaban yaitu: $\mathrm{SB}=4, \mathrm{~B}=3$, $\mathrm{KB}=2, \mathrm{~TB}=1$. Dari item pernyataan terdapat 5 item jawaban $\mathrm{B}=3$ katagori Baik, terdapat 3 jawaban $\mathrm{SB}=4$ kategori Sangat Baik. Dari perhitungan di atas didapatkan presentase sebesar $84,38 \%$.

Tabel 1.2 Rekapitulasi persentase Hasil Uji literasi membaca dan hasil validasi ahli media bagi guru

\begin{tabular}{clcc}
\hline No & Validator & $\begin{array}{c}\text { Persentase } \\
\text { Perolehan }\end{array}$ & Kriteria Penilaian \\
\hline 1. & $\begin{array}{l}\text { Uji literasi Membaca sisiwa } \\
\text { dengan menggunakan } \\
\text { multimedia Interaktif flash }\end{array}$ & $86,8 \%$ & Layak, sedikit perbaikan \\
\hline 2. & Ahli media bagi guru & $90,19 \%$ & Layak, sedikit perbaikan \\
\hline
\end{tabular}

Hasil uji tingkat literasi verbal siswa dan hasil validasi ahli media bagi guru dengan menggunakan multimedia interaktif adof flash cs 06 mendapatkan hasil yang layak dan valid. Pada hasil uji literasi verbal siswa mendapatkan skor 43 dengan dibagikan jumlah indicator yang muncul mendaptkan hasil skor 86, artinya literasi verbal siswa sangat baik sehingga multimedia interaktif ini dapat meningkatkan keaktifan siswa dalam membaca. Pada tingkat uji validasi oleh guru dengan 
Dwi, Farida. Multimedia Interaktif tipe Adobe...

menggunakan multimedia interaktif dengan menggunakan kurikulum 2013 mendapatkan skor 90 artinya media tersebut layak untuk di aplikasikan dikelas baik kelompok kecil maupun kelompok besar.

\section{PEMBAHASAN}

Pada Prodak pengembangan multimedia Interaktif Adobe flash CS6 memiliki kevalidan, kepraktisan, keefektifan yang layak digunakan dalam kegiatan pembelajaran disekolah dasar. Arkun (2008:16) Penggunaan multimedia interaktif akan membuat siswa merasa senang dan termotivasi dalam pembelajaran dan berdampak positif bagi peningkatan prestasi belajar siswa, (Akbar, 2016) mengemukakan bahwa dengan temuan penelitian multimedia interaktif membuat siswa merasa tertarik (Tiari \& Suryani, 2016) dengan adanya media yang kreatif menambah minat belajar. (Rahmat \& Techno, 2015) Dalal (2014:10) mengemukakan bahwa Penggunaan multimedia interaktif juga dapat meningkatkan hasil belajar siswa dan prestasi belajar. Dikshit (2013:208) menegaskan penggunaan multimedia interaktif dalam pembelajaran lebih efektif dengan beragam aktivitas dari pada melalui buku teks. Daryanto (2013:5) menegaskan bahwa multimedia Interaktif dapat memberikan alternative dalam memenuhi kebutuhan belajar siswa terutama akan kebutuhan media pembelajaran yang mampu memperjelas materi pembelajaran meningkatkan keaktifan belajar siswa. Smaldino (2011:7) mengungkapan juga bahwa tujuan dari penggunaan media adalah untuk memudahkan komunikasi dan belajar.

Pada takaran prodak pengembangan multimedia Interaktif ini divalidasi oleh ahli materi dan ahli media. Hasil validasi ahli materi mencapai $87 \%$ dengan kriteria sangat valid dan dapat digunakan karena pada Pengembangan multimedia interaktif ini didasari adanya masalah keterbatasan media dalam proses pembelajaran tematik khususnya pada tema 2 , subtema 2 bermain dirumah teman, pembelajaran 4 . Terdapat berbagai alternatif media yang dikembangkan di era perkembangan IPTEK seperti sekarang ini. Haryono, 2015:107) pada sistem multimedia yang mampu menyuguhkan tampilan teks, gambar, suara, dan animasi. Multimedia interaktif dinilai cocok untuk mengantarkan materi ini karena dapat melibatkan animasi, dan juga audio sehingga anak merasa lebih tertarik untuk belajar dibanding hanya menggunakan media buku teks. Dengan menggunakan multimedia interaktif terdapat beberapa komponen yang menarik dalam inovasi 
Dwi, Farida. Multimedia Interaktif tipe Adobe...

pengembangannya diataranya adalah (1) judul program yang merupakan bagian penting untuk memberikan informasi kepada sisiwa tentang apa yang akan ia pelajari dan dia baca (2) Terdapat menu petunjuk yang berisikan informasi tentang kompetensi dan cara penggunaan multimedia interaktif (3) terdapat menu kompetensi yang berisikan standart kom petensi dan indicator pembelajaran yang akan di capai. (4) terdapat unsur literasi verbal dalam meningkatakan kompetensi sisiwa dalam membaca dan belajar secara mandiri.(5) Terdapat menu game yang bisa di aplikasikan dalam pembelajaran sesuai dengan materi yang mnarik. (6) terdapat menu profil pengembang yang berisikan nama pengembang multimedia interaktif

Hal ini sesuai dengan kelebihan multimedia interaktif menurut Haryono, (2015:107) yaitu siswa diajak untuk terlibat secara auditif, visual, dan kinestetik sehingga dimungkinkan informasinya mudah dimengerti. Selama uji coba lapangan terbatas, siswa tampak antusias dan serius belajar karena pembelajaran menggunakan multimedia interaktif menarik. Hal ini ditunjukkan dengan tingginya presentase, yaitu $83,33 \%$, pada uji coba lapangan lebih luas siswa tampak antusias dan serius belajar karena pembelajaran menggunakan multimedia interaktif menarik. Hal ini ditunjukkan dengan tingginya presentase, yaitu 92,67\%. Sadiman (2010:17) mengungkapkan bahwa dengan menggunakan kurikulum 2013 pada pemanfaatan multimedia Interaktif Adobe flash CS6 yaitu untuk memperjelas penyajian pesan agar tidak terlalu verbalistis dan mengatasi keterbatasan ruang, waktu dan daya indera. Agar penyampaian materi dapat tersampaikan dengan baik dan tujuan pembelajaran dapat tercapai, maka perlu adanya kejelasan antara kompetensi dasar, indikator dan tujuan pembelajaran yang sesuai dengan kebutuhan siswa serta harus berorientasi pada siswa.

Pada hasil uji literasi verbal siswa mendapatkan skor 43 dengan dibagikan 12 jumlah indikator yang muncul mendaptkan hasil 86,20 artinya literasi verbal siswa sangat baik sehingga pemanfaatan multimedia interaktif ini dapat meningkatkan keaktifan siswa dalam membaca. Literasi verbal siswa merupakan kompetensi berbahasa siswa dalam penguasaan mencakup kemampuan mendapatkan informasi dalam teks serta mengkomunikasikan kembali hasil pemerolehan informasi tersebut melalui aktivitas berbahasa yang lainnya (Resmini, 2003:6). Seseorang dikatakan memiliki literasi verbal dalam kompetensi berbahasa jika memiliki kemampuan atau keterampilan berbahasa yang baik dengan empat aspek keterampilan di dalamnya antara 
Dwi, Farida. Multimedia Interaktif tipe Adobe...

lain keterampilan membaca, menulis, menyimak, dan berbicara (Sunarti \& Nursalim, 2018:13). Keterampilan-keterampilan berbahasa tersebut disajikan dalam multimedia Interaktif berbasis literasi verbal siswa dalam membaca dengan penyajian bacaanbacaan dalam multimedia interaktif rubrik ayo kita membaca yang kemudian didukung dengan pemberian tugas-tugas pendukung dalam rubrik ayo kita menulis, ayo kita menyimak, ayo kita menyampaikan, ayo kita lakukan, ayo kita cari tahu, ayo kita berdiskusi, serta ayo kita menalar yang kesemuanya saling dipadukan untuik mendukung lietasi verbal siswa dalam berbahasa.

Literasi verbal siswa dalam kaitannya dengan Minat membaca yang baik juga akan menjadikan siswa mandiri sepanjang hayat, kreatif, dan mampu memecahkan masalah dengan cara menggunakan kemampuan berbahasanya (Nurdiyanti \& Suryanto, 2010:117) sehingga memiliki kamampuan dalam memahami isi suatu bacaan. Kemampuan tersebut dapat membantu siswa dalam meningkatkan kemampuan berpikir kritis sebab dalam membaca siswa akan mengalami proses berpikir untuk memahami ide secara luas (Pujiono, 2012:778). Kemampuan berpikir kritis sangat diperlukan dalam menganalisis secara sistematis dan spesifik permasalahan yang dihadapi secara cermat dan teliti untuk mengidentifikasi informasi yang diperlukan guna merencakan strategi pemecahan masalah (Azizah, dkk., 2018:62). Pembelajaran yang memerlukan lebih banyak strategi pemecahan masalah.

Dapat disimpulkan bahwa dengan uji literasi verbal sisiwa dengan hasil yang sangat valid pada pembelajaran menggunakan media pembelajaran dapat menarik perhatian siswa untuk belajar. Awal pembelajaran siswa sudah menunjukan ketertarikannya dengan multimedia interaktif terbukti dengan keikut sertaan siswa dalam menyanyikan lagu indonesia raya dan membaca teks "waktu aku lomba menar" siswa membaca bersama-sama dengan suara lantang dan penuh semangat, dan saat pembelajaran siswa sangat aktif dan tidak ada yang merasa ngantuk dan jenuh saat pembelajaran berlangsung. Perbandingan multimedia interaktif yang peneliti buat berbeda dengan pengembangan yang lain karena belum ada yang mengambil penelitian di kelas II pada tema 2, subtema 2, pembelajaran 4, pembahasan penelitian terkait dengan literasi verbal siswa berorientasi kurikulum 2013 dimana mencakup pembuatan silabus, rpp, media, penekanan pada materi lebih di tonjolkan dan disesuaikan dengan kondisi siswa serta soal yang dibuat dikembangkan sendiri oleh peneliti untuk 
Dwi, Farida. Multimedia Interaktif tipe Adobe...

mempermudah pemahaman siswa kelas II disajikan dengan soal yang menarik dan berbeda dengan buku siswa dan buku guru, gambar yang disediakan beragam sesuai dengan materi yang di ajarkan dan beragam animasi yang menarik yang membuat siswa semangat untuk belajar.

\section{Tabel 1.3 Perbedaan produk awal dan produk akhir}

\begin{tabular}{|c|c|c|}
\hline Aspek & Produk Awal & Produk Akhir \\
\hline Media & $\begin{array}{l}\text { 1. Backgroun pada SBDP yang } \\
\text { digunakan berwarna putih } \\
\text { transparan dan erlalu dominan. } \\
\text { 2. Tulisan tombol teks kurang } \\
\text { sesuai. } \\
\text { 3. tombol kurang untuk } \\
\text { mempermudah pengoperasian }\end{array}$ & $\begin{array}{l}\text { 1. Backgroun di ganti } \\
\text { dengan warna hitam transparan supaya } \\
\text { gerakan tarian terlihat jelas oleh siswa. } \\
\text { 2. Tulisan tombol teks diganti dengan } \\
\text { tulisan materi. } \\
\text { 3. Penambahan tombol next dan back } \\
\text { ditambahkan. }\end{array}$ \\
\hline Materi & $\begin{array}{l}\text { 1. Materi masih sedikit. } \\
\text { 2. Soal masih sedikit. } \\
\text { 3. tidak ada teks sya'ir lagu pada } \\
\text { materi SBDP. } \\
\text { 4. Gambar-gambar masih sedikit }\end{array}$ & $\begin{array}{l}\text { 1. Penambahan materi pada perkalian } \\
\text { sifat bilangan. } \\
\text { 2. Penambahan soal pada perkalian. } \\
\text { 3. Menambahkan teks sya'ir lagu supaya } \\
\text { siswa menari dan menyanyi. } \\
\text { 4. Penambahan gambar-gambar yang } \\
\text { meanrik. }\end{array}$ \\
\hline Bahasa & $\begin{array}{l}\text { 1. Materi yang ditampilkan } \\
\text { berbentuk paragraf. }\end{array}$ & $\begin{array}{l}\text { 1. Tampilan materi dirumah tidak dalam } \\
\text { bentuk paragraf. }\end{array}$ \\
\hline Guru & 1. Tidak ada petunjuk penggunaan & $\begin{array}{l}\text { 1. Petunjuk penggunaan dibuat seperti } \\
\text { buku petunjuk dalam lembaran. }\end{array}$ \\
\hline
\end{tabular}

Berikut ini adalah tampilan dari prodak akhir multimedia interaktif tema 2, subtema 2 bermain dirumah teman, pembelajaran 4 .

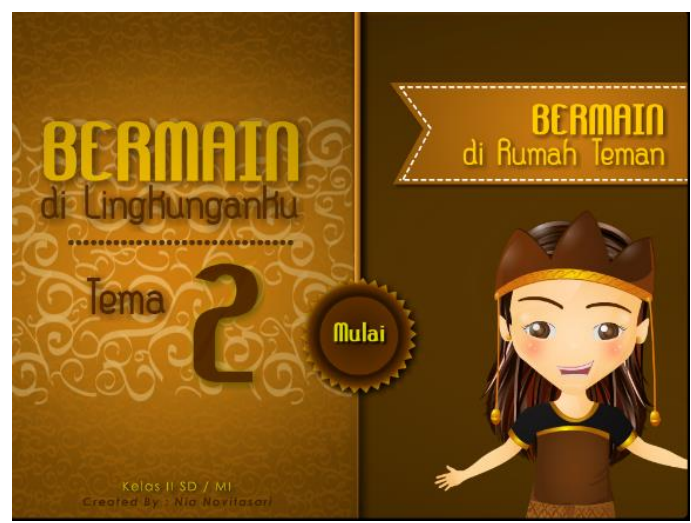

Gambar 1.1 Tampilan utama produk akhir

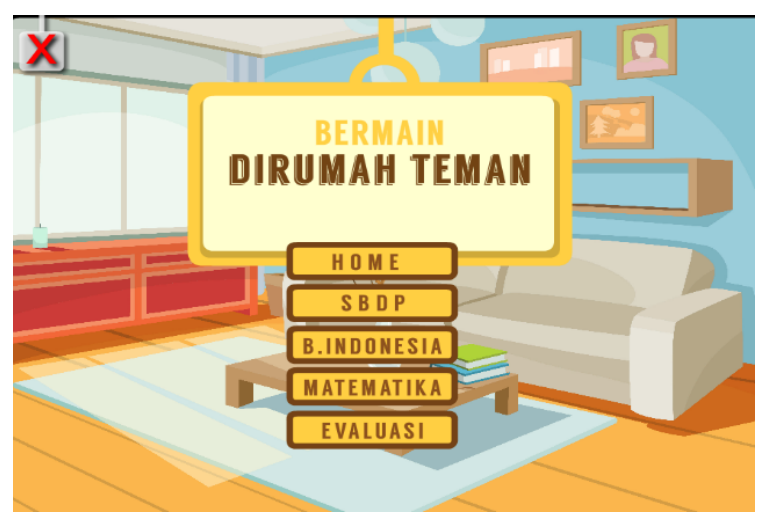

Gambar 1.2 Menu utama produk akhir 
Dwi, Farida. Multimedia Interaktif tipe Adobe...
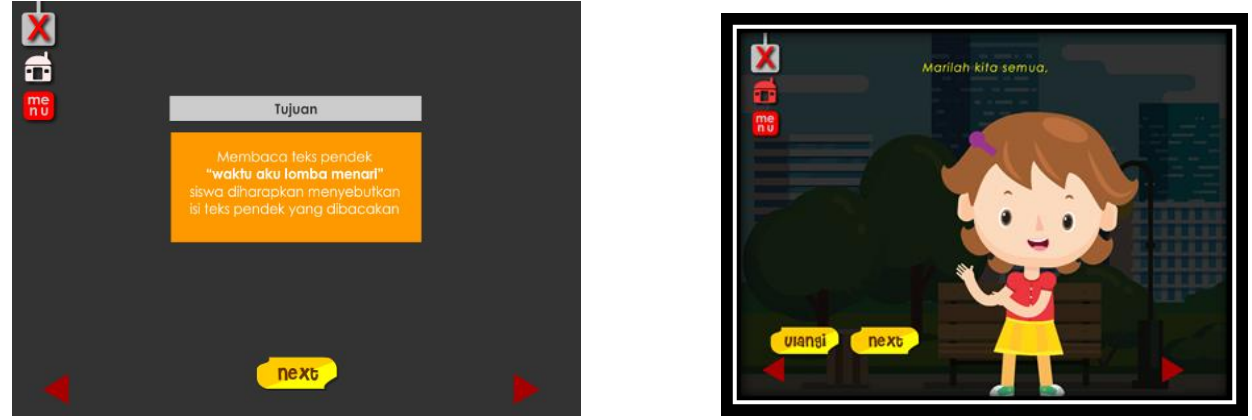

Gambar 1.3 Tujuan pembelajaran akhir
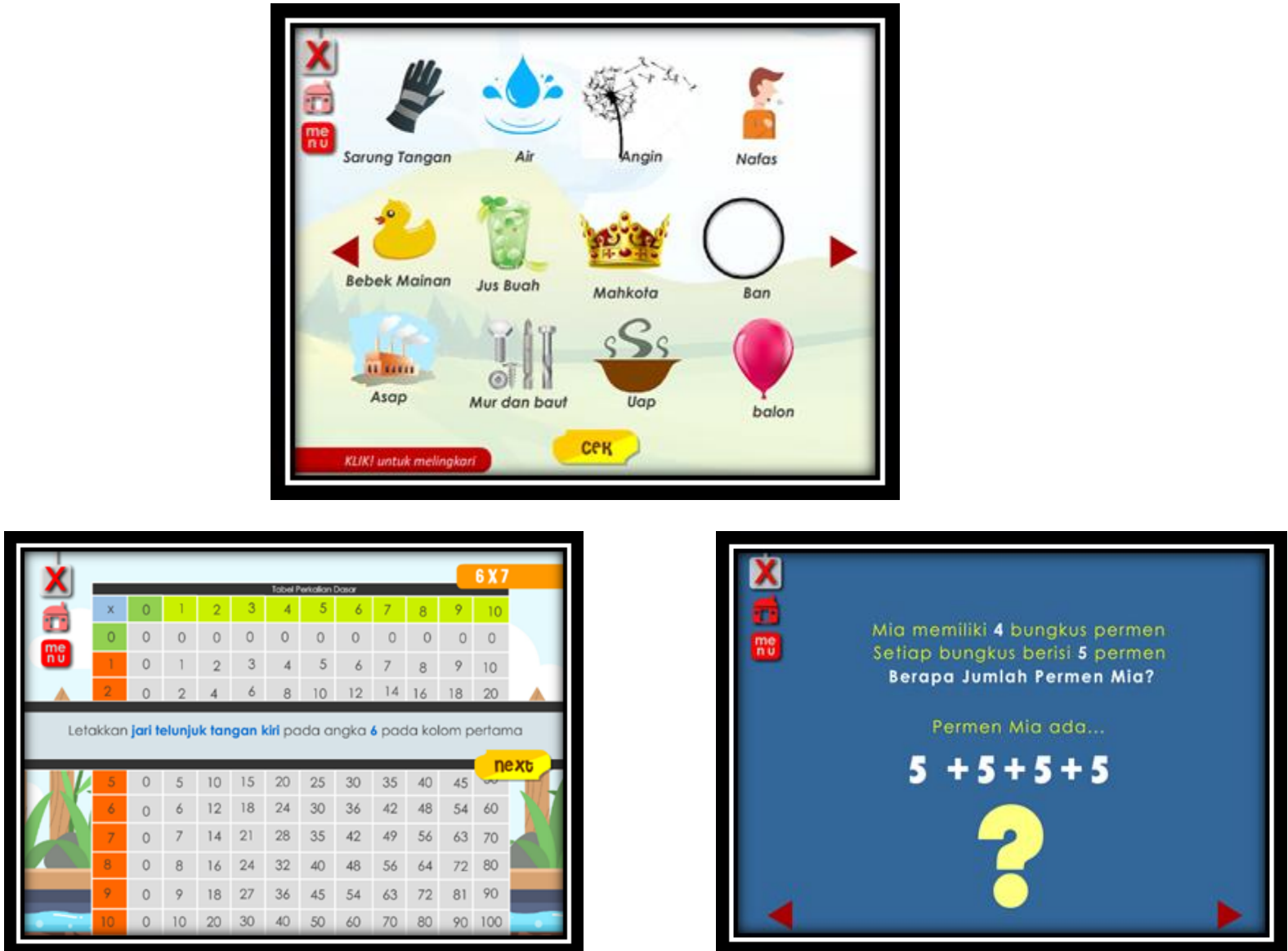

Gambar 1.4 Materi produk akhir

\section{SIMPULAN}

Berdasarkan validasi ahli media, validasi ahli materi, validasi ahli bahasa, dan hasil ujicoba kepada guru dan siswa diperoleh hasil bahwa buku teks berbasis literasi membaca untuk kelas II dinyatakan layak, praktis, dan terbaca sehingga dapat diimplementasikan dalam pembelajaran. Penggunaan buku teks berbasis literasi membaca menambah daya dukung minat membaca siswa dengan adanya gambar- 
Dwi, Farida. Multimedia Interaktif tipe Adobe...

gambar menarik serta komposisi warna dalam setiap penyajian isi materi dan rubriknya sehingga mendorong keterampilan berbahasa dan kemampuan berpikir kritis siswa. Penyajian keseluruhan materinya dikaitkan dengan kemampuan literasi membaca dengan didukung multimedia Interaktif untuk mendukung kemampuan literasi siswa yang dibutuhkan dalam pembelajaran abad 21 saat ini.

\section{UCAPAN TERIMA KASIH}

Agar produk yang dihasilkan dapat dimanfaatkan secara maksimal dalam pembelajaran, terdapat beberapa saran yang terkait dengan buku teks berbasis literasi membaca sebagai berikut.

1. Guru dapat menggunakan Multimedia Interaktif Adobe flash CS6 berbasis literasi verbal sebagai pendamping bahan ajar siswa yang biasa digunakan.

2. Perlu diadakan penelitian lanjutan untuk menguji Media Interaktif berbasis literasi verbal aspek membaca agar produk lebih sempurna dengan penambahan variasi soalsoal evaluasi, Lembar Kerja Siswa (LKS), maupun Lembar Kerja Peserta Didik (LKPD).

3. Perlu diadakan penelitian lanjutan untuk menguji pengembangan multimedia Interaktf adop flash berbasis literasi verbal aspek membaca dengan menggunakan penelitian dan pengembangan model Addie sampai tahapan terakhir yaitu tahap diseminasi yang merupakan tahapan penyebarluasan produk dalam skala yang lebih luas.

4. Perlu dikembangkan media interaktif adop flash berbasis literasi membaca dengan menambah gambar-gambar dan konten-konten lietrasi verbal dan visual mengenai kemampuan literasi dan numerasi dengan menggabungkan pembelajaran yang kontekstual dengan kurikulum 2013 di dalamnya agar bahan ajar dalam bentuk multimedia Interaktif ini menjadi lebih lengkap dan bisa digunakan sebagai pegangan siswa.

5. Perlu dikembangkan multimedia Interaktif adop flash berbasis literasi membaca dengan cakupan materi pembelajaran yang lebih luas misalnya untuk pembelajaran dalam periode dua semester atau satu tahun pembelajaran. 
Dwi, Farida. Multimedia Interaktif tipe Adobe...

\section{DAFTAR RUJUKAN}

Akbar, T. N. (2016). Pengembangan Multimedia Interaktif Ipa Berorientasi Guided Inquiry Pada Materi Sistem Pernapasan Manusia Kelas V Sdn Kebonsari 3 Malang. Jurnal Pendidikan: Teori, Penelitian, Dan Pengembangan Volume: 1 Nomor: 6 Bulan Juni Tahun 2016 Halaman: 1120-1126, 1120-1126. Retrieved from EISSN: 2502-471X

Arkün, S. \& Akkoyunlu, B. 2008. A Study on the Development Process of a Multimedia Learning Environment According to the ADDIE Model and Students' Opinions of the Multimedia Learning Environment. Interactive Educational Multimedia University of Barcelona, (17). (Online), (http://www.raco.cat/index.php/iem/article/viewFile/205357/273895), diakses 17 Oktober 2015.

Dalal, M. 2014. Impact of Multimedia Tutorials in a Computer Science Laboratory Course-An Empirical Study.The Electronic Journal of e-Learning, 12 (4). (Online), (http://files.eric.ed.gov/fulltext/EJ1035651 .pdf), diakses 17 Oktober 2015 .

Daryanto. 2013. Media Pembelajaran: Peranannya Sangat Penting dalam Mencapai Tujuan Pembelajaran. Yogyakarta: Gava Media.

Dikshit, J., Garg, S., \& Panda, S. 2013. Pedagogic Effectiveness of Print, Interactive Multimedia, and Online Resources: A Case Study of Ignou. International Journal of Instruction,6 (2). (Online),(http://files.eric.ed.gov/fulltext/ ED544083.pdf), diakses 1 November 2015

Hartanto, A. (2013). Pembelajaran matematika materi bangun ruang dan balok dengan aplikasi multimedia interaktif di sd negeri teguh sragen, 2(1), 85-89. Retrieved from seruniid.unsa.ac.id

Kurniati. (2016). Modul komunikasi verbal dan non verbal. Modul Komunikasi Verbal dan Non Verbal.

Kusprimanto. 2014. Pengembangan Media Pembelajaran Interaktif Ipa Materi Pencernaan Pada Manusia Untuk Siswa Kelas V Di SDN Pundung, Girirejo, Imogiri, Bantul, Yogyakarta. Skripsi Tidak Diterbitkan. Yogyakarta: Universitas Negeri Yogyakarta

Kurniawati, Rissa Prima 2014. Pembelajaran Berbantuan Multimedia Berdasarkan Cognitive Load Theory Pada Pelajaran Matematika SD. Vol 4. No.1: 79-88.

Lau, N. S. A., Setiawan, D. A., \& Werdiningtiyas, R. K. (2019). Literasi Verbal Siswa pada Keterampilan Berbicara pada Siswa Kelas III di SDN Kebonsari 4 Malang Program Studi Pendidikan Guru SD , Universitas Kanjuruhan Malang, Https://conference.unikama.ac.id/artike/, 3(November), 197-210.

Nurgiyantoro, B., \& Suyata, P. (2011). Model Penialian Otentik Pembelajaran Bahasa. LITERA, Volume 10, Nomor 2, Oktober 2011 Universitas Negeri Jogjakarta, Volume 10, 114-125.

Putry, I. F. L., \& Agung Listiadi”. (2012). Pengembangan Bahan Ajar Berbasis Multimedia Presentasi Interaktif Pada Materi Jurnal Penyesuaian Perusahaan 
Dwi, Farida. Multimedia Interaktif tipe Adobe...

Dagang Untuk Mendukung Pembelajaran Akuntansi Sma Negeri 1 Gresik. Jurnal Universitas Negeri Surabaya", Volume $01,1-6$.

Pribadi, Benny. 2014. Desain dan Pengembangan Program Pelatihan Berbasis Kompetensi Implementasi Model ADDIE. Jakarta: Prenada Media Group.

Resmini, N. 2003. Peningkatan Kompetensi Berbahasa dan Kompetensi Matematika Siswa Sekolah Dasar Melalui Pembelajaran Terpadu Berbasis Masalah. Journal of Chemical Information and Modeling. (1-39). doi: 10.1017/CBO9781107415324.004.

Sadiman. S Arif, Rahardjo, Haryono Anung \& Harjito. 2007. Media Pendidikan: Pengertian, Pengembangan dan Pemanfaatannya. Jakarta: Raja Grafindo Persada.

Setiadi, H. (2016). Pelaksanaan Penilaian Pada Kurikulum 2013. Jurnal Penelitian Dan Evaluasi Pendidikan Volume 20, No 2, Desember 2016 (166-178), 20(2). Retrieved from http://journal.uny.ac.id/index.php/jpep

Smaldino, S, Deborah, L. James, D. 2011. Intructional Technology and Media for Learning: Teknologi Pembelajaran dan Media untuk Belajar. Jakarta: Kencana.

Susiana, A., Harningsih, S., \& Napitupulu, E. (2014). Penggunaan Multimedia Pembelajaran Interaktif Dan Kreativitas Terhadap Hasil Belajar Teknologi Informasi Dan Komunikasi (Tik). Jurnal Teknologi Informasi \& Komunikasi Dalam Pendidikan, 1(1), 24-37.

Sunarti \& Nursalim. 2018. Kompetensi Bahasa Anak. Jurnal Ilmiah Pendidikan Bahasa dan Sastra. Vol.4(2), ( 8-19).

Sugiyono, 2015. Metode Penelitian Kuantitatif, Kualitatif dan R\&D. Bandung : 